\title{
The Effect of Work Loyalty and Work Ethics on Teacher's Career in Banjar District
}

\author{
Deby Marsadina ${ }^{*}$, Cepi Safruddin Abd Jabar
}

\author{
Universitas Negeri Yogyakarta, Indonesia \\ *Corresponding author. Email: debi.app.net@gmail.com
}

\begin{abstract}
The study aims to determine work loyalty and work ethic in teacher careers in Banjar Regency. The method used in this research is an explanatory quantitative approach. The data collection technique in this research is observation, and the questions made by the researcher are arranged with the respondents can choose. Analysis of the data in this study using simple regression analysis techniques and multiple analysis. The results show that 1 . there is an influence of loyalty on teacher careers obtained from Rcount $>$ Rtable with a level of 5\%, so $0.395>0.195$. R Square of 0.156 or $15.6 \%$. The $\mathrm{F}$ value is 19,036 with a significance level of $0.000(0.000<0.05)$. The $\mathrm{t}$ test result is $4.363>\mathrm{T}$ table 1.983 that Ho is rejected and Ha is accepted. 2. There is an influence of work ethic on teacher career. These results are obtained from Rcount $>$ Rtable with a level of $5 \%$, so that $0.431>0.195$. R Square of 0.186 or $18.6 \%$. The $\mathrm{F}$ value is 23,501 with a significance level of $0.000(0.000<0.05)$. The $t$ test result is $4.848>\mathrm{T}$ table 1.983 that Ho is rejected and $\mathrm{Ha}$ is accepted. 3. There is an effect of work loyalty and work ethic on teacher careers. These results are obtained from Rcount $>$ Rtable with a level of $5 \%$ so that $0.446>0.195$. R Square 0.199 or $19.9 \%$ means the contribution of variables and work ethic to career is $19.9 \%$ where the two independent variables influence the variable, namely the teacher career variable.
\end{abstract}

Keywords: teacher career, work ethic, work loyalty

\section{INTRODUCTION}

Teachers are professional educators who teach, educate, and provide direction to their students to get a quality education to achieve educational goals. A teacher is one of the critical roles in advancing education and the quality of education, therefore teachers must have the skills and insights to become professional teachers.

The duties and responsibilities of teachers are to manage to teach effectively, dynamically, efficiently, and positively which is characterized by awareness and involvement between two subjects, teachers who initiate and direct, and guide. These students experience and are actively involved in gaining self-change in teaching[1].

A career is a director of professional progress, a word whose use is limited to occupations that have a formal hierarchy of advancements, such as managers and other professional disciplines. A career is also defined as a series of work experiences of a person who undergoes changes or developments[2].

Previous research revealed that teacher career development at SMP Negeri 1 Muara Pinang was in assignments. Promotions were carried out by the results of teacher performance assessments by school principals, which positively impacted teachers to improve their competence so that teachers gained the confidence to carry out the assigned tasks[3].

A teacher's career is an improvement achieved by a teacher during his tenure. Teacher career advancement is obtained from the promotion during their working period. Teacher careers were seen from the class teacher in 2016 and 2017. There were 3,768 and 4,046 class teachers from groups 1 to 4 in 2016 and 2017, respectively, in Banjar District. During that year, there was an increase in groups 1 and 3, which was $2 \%$, and the decrease was in group 2 by $1 \%$ and group 4 by $3 \%$. 
The goal of career developments are to (1) develop skills so that work can be completed quickly and more effectively; (2) develop knowledge so that work can be done rationally; (3) develop attitudes to create a willingness to cooperate with fellow employees and leaders[4].

One way to improve teacher careers is that teachers must be willing to sacrifice themselves for the progress of the school and their students to achieve educational goals. Teachers are also ready to carry out selfmonitoring and serve the school wholeheartedly; this is a form of teacher self-loyalty. This willingness to sacrifice oneself involves awareness to devote oneself to an institution. Loyalty is also supported by previous research that there is a positive influence between career development on teacher loyalty by $11.2 \%$. And there is a positive influence between career development and interpersonal relationships on teacher loyalty by $51.7 \%$ [5].

Employee loyalty is a form of loyalty that is described from the willingness of employees to maintain and maintain the organization inside and outside of work from irresponsible things[6].

The higher the loyalty of employees in an organization, the easier it is for the organization to achieve e organization leadership of the organization has set. Teacher loyalty is the only factor behind the success of academic institutions. Loyalty is a multidimensional phenomenon that originates from Reichheld's em, empowerment, participation, and socialization. So loyalty is a trait possessed by individuals at work that is formed in loyalty to maintain an organization both inside and outside the environment.

Three factors influence loyalty, namely, 1. Security factors include years of service, salary, work safety, and social security, 2. Comfort factors include the work environment, fellow employees, and adequate facilities, 3. Challenge factors include clarity of career paths felt by all employees [8].

One of the characteristics of human resources expected by developed and developing countries is citizens who have a high work ethic. If an employee has a high work ethic, he will get a goal in improving performance. Work ethic is rooted in fundamental beliefs and a commitment to an integral work paradigm [10].

One of the successes of teachers is self-motivation and working earnestly in carrying out their duties. Therefore the quality of education will move quickly with the teacher's work ethic. Work ethic is a good work spirit based on specific values or norms. Work ethic is a cultural norm that supports a person to do and be responsible for his work based on the belief that the work has intrinsic value [11]. Successful humans must have views and attitudes that value work as something noble for their existence, called work ethic [12].

This is in line with previous research that there is a significant influence between work ethic on the career development of Banda Aceh Mayor's Office employees; the positive value contained in the work ethic and employee career development is that if the work ethic increases, the career development of employees also increases, therefore work ethic has a significant influence on employee careers [13]. So work ethic is a spiritual attitude carried out by individuals based on applicable values and norms responsible for their work and organization.

\section{METHODS}

This research is included in explanatory research or explanatory research (quantitative explanation); this research is used to obtain information from respondents and test hypotheses. The time and place of the study were carried out in June-July, and the research location was in Banjar Regency as many as eight junior high school and Islamic junior high schools. The populations were 150 teachers, and the sample was 105 teachers, which was taken using a table determining the number of representatives from a purposive population with an error rate of $5 \%$. The data in this study were collected using observation and questionnaires by employing a Likert scale. Data were analyzed used simple regression analysis techniques and multiple regression analysis; simple regression analysis was used to determine the effect of the $\mathrm{X}$ variable with the $\mathrm{Y}$ variable and multiple regression analysis to determine the effect of the $\mathrm{X} 1, \mathrm{X} 2$ variables on $\mathrm{Y}$

\section{RESULTS AND DISCUSSION}

\subsection{The Effect Of Loyalty On Teacher Career}

To determine the effect of work loyalty on the teacher's career, calculations were carried out with the help of the SPSS 25 application. The regression analysis results obtained $\mathrm{R}$ arithmetic of 0.395 greater than $\mathrm{R}$ table 0.195 at $5 \%$ level and $\mathrm{N}=105$. It can be concluded that the loyalty variable positively affects teacher careers. R Square (coefficient of determination) is 0.156 or $15.6 \%$, which means that the contribution of the loyalty variable to the teacher's job is $15.6 \%$, while other factors can explain the remaining $84.4 \%$; these factors can be internal factors or external factors. The calculation of linear regression analysis results produces an $\mathrm{F}$ value of 19,036 with a significance level of 0.000 $(0.000<0.05)$ so that this regression model can be used to predict the loyalty variable. 
The significance test aims to determine the significance of the loyalty variable on the teacher career variable. After the T-test, the results obtained are 4.363, which is greater than the $\mathrm{T}$ table with a level of $5 \%$ with $\mathrm{df}=1031.983$ with a significance of $0.000<0.05$, and it can be concluded that Ho rejected, and Ha accepted so that loyalty has a significant effect on the teacher's career.

The coefficient is known to be 0.295 , and the constant number is 27.560 . These results can be used as a simple linear regression line, namely: $\mathrm{Y}=27.560+$ (0.295). This means that each addition of one discipline value will increase the career value by 0.295 or $29.5 \%$. From the aforementioned explanation, it can be concluded that the teacher loyalty can affect teacher careers.

Loyalty is an identification of the sense, involvement raised by employees towards the organization and is shown in an attitude of acceptance, a strong belief in the values and goals of an organization, and a solid drive to maintain membership in the organization to achieve goals [14]. This finding is supported by previous research which found that data analysis found $39 \%$ of respondents had low loyalty, and $61 \%$ had firm belief; $48.2 \%$ of respondents had low general satisfaction, and $51.8 \%$ had high pleasure, $44 \%$ had low integrity, and $56 \%$ had high integrity. Variables that affect loyalty are integrity, satisfaction with salary, school rules, and co-workers. The higher the components of integrity and satisfaction with wages, regulations, and co-workers, the higher the loyalty of teachers in Kupang. So that in this study, it has a high commitment of $61 \%$ [15].

In addition, research shows that there is an influence between loyalty and teacher careers seen from the results of hypothesis testing at an error rate of 5\%, namely, count $=18.794>\mathrm{f}$ table $=3.35$ then the hypothesis is accepted, which means that there is an influence simultaneously between leadership and career development on employee loyalty at PT. The difference is career variable two and loyalty variable $\mathrm{Y}$ and discusses the employees of PT. BPRS Al Salaam Amal Salman [16]. Thus, from the analysis results, it can be concluded that work loyalty affects teacher careers in the Banjar district. Job loyalty has a reasonably close influence on the teacher's career; the more the teacher's work loyalty increases, the more the teacher's career will increase.

\subsection{The Influence Of Work Ethic On Teacher Career}

The work ethic influences the teacher's career, evidenced by the regression calculations assisted by
SPSS 25. The regression analysis results obtained that the $\mathrm{R}$ count was 0.431 , more significant than the $\mathrm{R}$ table 0.195 at the $5 \%$ level and $\mathrm{N}=105$. It can be concluded that the ethos variable positively affects teacher careers. $\mathrm{R}$ Square (coefficient of determination) is 0.186 or $18.6 \%$, which means that the contribution of the ethos variable to the teacher's job is $18.6 \%$. In comparison, other factors can explain the remaining $81.4 \%$; these factors can be internal. Or external. The calculation of linear regression analysis results in an $\mathrm{F}$ value of 23,501 with a significance level of $0.000(0.000<0.05)$ so that this regression model can be used to predict the ethos variable.

The significance test aims to determine the significance of the ethos variable on the teacher career variable. After testing the T-test, the results obtained are 4.848 , which is greater than the $\mathrm{T}$ table with a level of $5 \%$ with df $=1031.983$ with a significance of 0.000 $<0.05$ and it can be concluded that Ho rejected and $\mathrm{Ha}$ accepted so that the ethos has an effect and is significant on the teacher's career.

The coefficient is known to be 0.245 , and the constant number is 24.322 . From these results, it can be used as a simple linear regression line, namely: $\mathrm{Y}=$ $24,322+(0.245)$. This means that each addition of one discipline value will increase the career value by 0.245 or $24.5 \%$. From the above explanation, it can be concluded that the teacher's ethos can affect a teacher's career.

The work ethic is to do activities or work harder to improve the results obtained [17]. Research on teacher career ethos can be seen in a previous study [18] that the correlation between teacher work ethic and career development is 0.769 . These results indicate a positive and significant relationship between teacher work ethic and career development at SMA Darussalam Blokagung with a potent category. The difference in this study is that it uses two variables, namely teacher ethos and career; the sample used is a teacher from SMA Darussalam Blokagung, who is a level higher than the research respondents, and this study uses a correlational type of research because it looks for relationships between variables. It is said that correlational research aims to determine the relationship between a variable with other variables.

It can be concluded from the results above that there is a strong influence of teacher ethos on teacher careers so that work ethic is an integral part of a teacher's career; work can bring fun and excitement at work so that creativity, new creations, and innovative ideas are born so that with a work ethic it will be increasingly influential in a teacher's career so that the goals he wants are achieved. 


\subsection{The Influence of Loyalty And Work Ethic On Teacher Career}

A teacher must make various efforts to improve four kinds of competencies, namely (personal, social, educational, and professional) so that their professional career can develop better-research or study of his professional work both individually and in groups [19].

Work loyalty and work ethic together affect teacher careers; it can be seen from the results of the regression analysis obtained that the $\mathrm{R}$ count is 0.446 , which is greater than $\mathrm{R}$ table 0.195 at the $5 \%$ level and $\mathrm{N}=105$. It can be concluded that the variables of loyalty and work ethic positively affect teacher careers. R Square (coefficient of determination) is 0.199 or $19.9 \%$, which means that the contribution of loyalty and work ethic variables to teacher careers is $19.9 \%$. In comparison, other supporting factors can explain the remaining $80.1 \%$ in the form of internal factors or external factors.

The calculation of linear regression analysis results produces an $\mathrm{F}$ value of 12.683 with a significance level of $0.000(0.000<0.05)$. This regression model can predict the variables of loyalty and work ethic.

The significance test aims to determine the significance of the loyalty and work ethic variables on the teacher career variable; after testing the T-test, the results obtained are 3.051, which is greater than the $T$ table with a level of $5 \%$ with $\mathrm{df}=1031.983$ with a significance of $0.000<0.05$, it can be concluded that Ho is rejected and $\mathrm{Ha}$ is accepted, so that loyalty and work ethic have a significant and significant effect on teacher careers.

It is known that the coefficients are 0.127 and 0.174 , and the constant number is 21.233 . From these results, it can be used as a simple linear regression line, namely: $\mathrm{Y}$ $=21,233+(0,127)+(0,174)$. This means that each addition of one value of loyalty and work ethic will increase the value of a teacher's career by 0.127 or $12.7 \%$ and 0.174 or $17.4 \%$, so it can be concluded that loyalty and work ethic can affect a teacher's career.

From these results, it can be concluded that work loyalty and work ethic influence a teacher's career. A career is the level of position or job that has been held by someone as long as that person has worked in an organization or company. Therefore, an individual with a promising career always has a good job or position [19].

\section{CONCLUSION}

The influence of work loyalty on teacher careers is seen from Rcount $0.395>$ Rtable 0.195, which means work loyalty influences teacher careers in Banjar Regency. The impact of work ethic on teacher careers is seen from Rcount $0.431>$ Rtable 0.195, meaning that work ethic influences teacher careers in Banjar Regency. There is a joint influence between work loyalty and work ethic on teacher careers in Banjar Regency by $19.9 \%$ based on Fcount while other supporting factors can explain the remaining $80.1 \%$.

\section{ACKNOWLEDGMENTS}

The writing of this journal was supported by Dr. Cepi Safruddin Abd Jabar, M.Pd as the supervising lecturer at the Faculty of Education Management for Postgraduate Education at UNY. Thank you for providing direction and insight in writing this journal. And we would like to congratulate ICCIE Yogyakarta State University for organizing this article writing event.

\section{REFERENCES}

[1] Rohani, Pengelolaan pengajaran. Jakarta:Renika Cipta. Jakarta: Renika Cipta, 2001.

[2] Rahmi Widyanti, manajemen karir (teori, konsep, dan praktik). Makassar: Rizky Artha Muliae, 2018.

[3] Zuzandi, Pengembangan profesi dan karir guru, $p$. 88, 2013, [Online]. Available: zuzandi1977@gmail.com hal $\quad 88$ file://C:/Users/uny/AppData/Local/Temp/728714898-1-PB-2.pdf.

[4] Moekijat, Manajemen sumber daya manusia (manajemen. kepegawaian). Bandung: Mandar Maju, 1999.

[5] Nurmi, Pengaruh pengembangan karir dan hubungan interpersonal terhadap loyalitas guru smp negeri kecamatan sukajadi kota pekanbaru, vol. Thesis, 2018, [Online]. Available: Riau: Program Pascasarjana Universitas.

[6] M. S. Hasibuan, Manajemen sumber daya manusia. Jakarta: PT Bumi Aksara., 2001.

[7] Utomo, Faktor-faktor yang mempengaruhi loyalitas konsumen. Jakarta: Salemba Empat, 2010.

[8] I. H. R. V. A. Ali Chaerudin, Sumber daya manusia: pilar utama kegiatan operasional organisasi. Jawa Barat: CV Jejak (Jejak Publisher), 2020.

[9] Harini ND and Handoyo, Etos kerja guru ips dalam implementasi keunggulan budaya lokal Tegal, J. Ilmu Sos. Pendidik., pp. 177-184., 2018.

[10] J. Sinamo, Delapan etos kerja profesional. Jakarta: Institut Mahardika, 2011.

[11] S. Santoso, Etos kerja pengusaha muslim perkotaan di kota Ponorogo, J. Penelit. Hum., no. 
ISSN 1411-5190, pp. pp. 115-125., 2006.

[12] Anoraga, manajemen bisnis. Jakarta: PT. Rinka Cipta, 1992.

[13] Darmansyah, Etos kerja dan pengembangan karir pegawai kantor wali kota banda aceh, J. Magister Manaj. Fak. Ekon. Dan Bisnis Unsyiah, no. ISSN 2302-0199, pp. 22-35, 2018, [Online]. Available: file://C:/Users/uny/AppData/Local/Temp/1023924860-1-SM.PDF.

[14] D. Gibson, Ivancevich, Organisasi: perilaku, struktur, proses. Jakarta: Binarup Aksara, 1997.

[15] Franky Franky Thomas Budiman, The analysis of integrity and satisfaction effect on teacher loyalty in Kupang, by Minist. Res. Technol. / Natl. Agency Res. Innov. Repub. Indonesia. Decree Number 28 /E / KPT / 2019, Rank 2 (Accredited B), valid until 2023., vol. Vol 9 No 1, p. 296, 2021, DOI: DOI : https://doi.org/10.33019/society.v9i1.296 Vol 9 No 1 (2021) Society.

[16] M. Febrian, Firdaus, and Asti, Pengaruh kepemimpinan dan pengembangan karir terhadap loyalitas karyawan., J. Manag., pp. 65-72, 2020, doi:

DOI: http://dx.doi.org/10.32832/manager.v3i1.3835.

[17] Nitisemito Alex, Manajemen personalia. Jakarta: Ghalia Indonesia, 2010.

[18] Budiyono and Sovitunnizar M.R, Implementasi undang-undang no. 14 tahun 2005 sebagai dasar hukum pada etos kerja guru dalam pengembangan karier, Tarbiyatuna, vol. ISSN: 2774, pp. 45-61, 2020.

[19] Tumpal B. M. Tambunan, pengembangan karir guru menuju indonesia emas, Semin. Nas. Pendidik. Dasar Univ. Negeri Medan, no. ISBN: 978-602-50622-0-9, p. 227, 2017. 